\title{
A Review of Human Issues in Horticulture in Finland: Urbanization Motivates a Renewed Appreciation for Plants and Nature
}

Aino-M aija Evers, ${ }^{1}$ Leena Lindén, ${ }^{2}$ and Erja Rappe ${ }^{3}$

ADDITIONAL INDEX WORDS. ecological gardening, environmental education, gardening and elderly, gardening in schools, human responses to nature, nearby nature

Summary. A pproaches using human issues in horticulture (H IH ) offer new possibilities to develop nearby nature in cities, especially during a period of rapid urbanization in Finland. $\mathrm{N}$ ew initiatives have been developed in school gardening, environmental education, gardening in training programs for disabled people, therapeutic environments in hospitals and institutions, and in the $U$ niversity of $\mathrm{H}$ elsinki horticultural education and research programs. At the $U$ niversity of $\mathrm{H}$ elsinki, two contact teaching courses and national seminars were organized in 1996 and 1998. I nitial studies in the H I H approach have three main themes: 1) gardening as a tool for better quality of life in homes for the elderly, 2) ecology, native plants and extensive maintenance in parks, and 3) the use of horticulture in environment and science education at the lower level of the comprehensive school.

F

inland has always been a country of forests, lakes, peatlands and sparse population. Forests, trees, waterways, rocks, fish, and berries are our natural resources, and Finns feel at home, safe and relaxed in these environments. In 1900 the proportion of the urban population was $12.6 \%$ while in 1930, 1960, and 1990 the proportions were $20.6 \% 38.4 \%$ and $61.6 \%$ respectively (Statistics Finland, 1996). In 1960 the labor force employed in agriculture numbered 721,000 persons, while in 1990 it was 170,000 persons, respectively (Statistics Finland, 1996). D uring three decades over 500,000 agricultural workers and their families left their rural, natural surroundings and moved to population centers and cities in southern Finland. Large suburbs with cheap apartments, big schools and hospitals were built outside the cities. L andscaping was modest due to lack of financial resources. During the boom of the 1980s, improvements were started, but the severe recession in the 1990s stopped this development.

The cost of publishing this paper was defrayed in part by the payment of page charges. U nder postal regulations, this paper therefore must be hereby marked adverti sement solely to indicate this fact.

${ }^{1}$ D epartment of Plant Production, P.O. Box 27, 00014 U niversity of H elsinki, Finland.

${ }^{2}$ Researcher

${ }^{3}$ Post doctoral student. 
A large part of the population still maintainsclose contact with agriculture and their nativerural places. M ost people living in towns are first or second generation urbanites. Gardening isfamiliar; $49.2 \%$ of households have somekind of place for growing plants (Tiainen et al., 1984). The total number of private kitchen gardens in 1982 was 867,700. Of these, $43.4 \%$ were in conjunction with one-family houses, $40.1 \%$ with farm houses, $9.2 \%$ with summer cottages, $5.1 \%$ with rented parcels, $1.3 \%$ with allotment gardens, and others $0.9 \%$ (Tiainen et al., 1984). The number of allotment gardens has increased from 15 in 1940 to 31 in 1970 and 48 in 1994 (Kauppinen, 1987). A special feature in Finland is the summer cottage, which is often located close to a Finn's native area (place where they were born and raised) and numbered 408,000 in 1994 (Statistics Finland, 1996). People drive long distances to their cottages on weekends and holidays. The desire for contact with nature is the driving force behind this. Because this contact is so necessary for relaxation, we should improve the quality of nearby nature in cities, suburbs, hospitals, schoolyards, and offices in order to improve the quality of life of ordinary citizens. An awareness of the huge changes in society and the poor quality of nearby nature in suburbs and institutions have been a motivating force behind the focus on human issues in horticulture $(\mathrm{HIH})$.

\section{An old application of HIH}

Thefather of Finnish public schools, U no Cygnaeus (1810-88), wasfamiliar with and thoroughly impressed by the educational ideas of J. J. R ousseau, J. H . Pestalozzi and F. Fröbel. Cygnaeus found gardening and school gardensan excellent means to teach the natural sciencesand practical horticultural skills, to promotechildren'sphysical and mental development, and to "cultivate the soul and heart for the benefit of human life and society" (Kalervo, 1913). H owever, it took several decades before the idea of school gardening spread more extensively among teachers and local school authorities.

In the early 20th century, wide enthusiasm for school gardening prevailed in Finland: horticulture was included in teacher training, the $\mathrm{N}$ ational Department of Public Education announced instructionsand model plansfor school gardens, and several books were published on the subject (Kalervo, 1915; $H$ yvönen, 1922). Theaim wasto decorate school grounds with ornamental settings as well as to train and educate students through practical work in kitchen gardens. Thus, children's sense of beauty, their knowledge of the natural sciences and even their moral and emotional development would be improved.

Atthat time, mostelementaryschools were rural with resident teachers. H ence, the site for school gardens and their summertime care were easily arranged. The few bigger cities sought to organize community garden plots to be cultivated by school children during the three-monthslong summer vacation.

School gardens were still valued right after World War II, when there was a shortage of food and other necessities in Finland. Since then, conditions havechanged substantially, and theideals of school gardening have been forgotten. Horticulture may still be included in the curriculum, now as an elective subject in the upper grades. In practice, few elementary schools carry out gardening activities: teachers feel their horticultural knowledge is inadequate and the fact that the school vacation coincides with the best growing season is an impediment. Nowadays, most Finnish schools are located in urban areas. School groundsareoften crowded and mostly paved, with little, if any, spacefor greenery. They seem to be planned not for education, nor for recreation, but first and foremost for easy maintenance.

Times are now changing: in the 1990s, a new awareness of the impact of the physical school environment has arisen in Finland. The $\mathrm{N}$ ational Board of Education has initiated a school ground project with the aim of promoting the use of school surroundings as a resource for all aspects of the curriculum. The ideal is an environment that enhances learning and gives children a wealth of experience in the four classical elements: air, water, fire and earth. O n the grassroots level, local projects to improve school grounds are being carried out here and there, usually with teachers and parents as initiators and communities providing material aid. In fact, school ground development isone of the main down-to-earth activities among parent-teacher associations.

\section{Current applications of HIH}

D uring the 1990s several authorities as well as local and private services have understood that the weak link for most communities and institutions is theenvironment. They haveintroduced gardening in their programs, focusing on environmental well-being. Some of Finland's promising projects are presented in the following section.

In H elsinki, the capital of Finland, one of the community gardeners has developed a program to teach very young children to enjoy, respect and nurture plants and plant populations. The program, started in 1995 and called Auntie Green, has been met with overwhelming enthusiasm among children, kindergardeners and parents. Furthermore, Auntie Green hasreceived widepublicity in newspapers, radio and TV: the program isnow expanding with new aunts and uncles being trained. In several smaller communities, children have been encouraged to participate in city planning and design (H orelli, 1997). The ultimate goal is to support the growth and development of children by means of horticulture in an urban environment.

TheAdaptation Training Centre for $D$ isabled togetherwith thecity of $L$ ahti has carried out a3-year-project (1995-97) to involve gardening in training programs designed to create a more meaningful life for disabled people. Persons with a brain injury or physical handicap have grown flowers and herbs in a city-owned greenhouse with the guidance of an occupational therapist, physiotherapist and gardener. The objective was to develop individual initiativeand enterprise. Theproject has been very successful and the line of action is being continued by the Adaptation Training Centre and the city garden

The Association of Finnish $L$ ocal and Regional Authoritiestogether with the $\mathrm{N}$ ational Research and $\mathrm{D}$ evelopment $\mathrm{C}$ entre for Welfare and $\mathrm{H}$ ealth has participated in the international U NESC O project Arts in $\mathrm{H}$ ospital. In Finland two hospitals, two homes for the elderly, and one nursing college looked for local opportunities to increase awareness of the importance of atherapeutic environment. Theproject produced local cultural and art activities and improvement in environments (Kokkola and Kotilainen, 1997).

\section{University involvement}

TheH IH approach wasintroduced in Finland at theU niversity of H elsinki's D epartment of $\mathrm{H}$ orticulture in 1993. It began byacquainting studentswith available literature on the subject. The first contact teaching course for students 
and graduatehorticultural specialistswas organized in 1996. A national seminar (Evers, 1996) was held in conjunction with the course. The 120 participants represented all walks of life: architects, horticultural students, hospital nursing staff and gardeners, local authorities, media, M inistry of J ustice, prison administration, social welfare for the disabled, teachers, and advisors. The discussions brought out the clear message that we should improve our immediate natural surroundings and open ourselves to contact with plants. The second courseand national seminar werein 1998 (Evers, 1998).

\section{HIH research at the University of Helsinki}

A number of students at the $U$ niversity of $\mathrm{H}$ elsinki have chosen to pursue graduate research in $\mathrm{HIH}$. The first doctoral thesisin $\mathrm{H} \mathrm{IH}$ was published in 1998 (L evander, 1998). O ther studies in this approach have concentrated on three main themes: 1) gardening as a tool for better life quality in homes for the elderly, 2) ecology, native plants, and maintenance in parks, and 3) the use of horticulture in environmental and science education. These are described below.

GaRDENING AS A TOOL FOR BETTER LIFE QUALTY IN HOMES FOR THE ELDERLY. The number of elderly people is increasing rapidly in Finland as well as in many other developed countries. Personsaged 65 and over make up $14 \%$ of the population, and it is estimated that $24 \%$ of the population will be 65 or older in 2030 (Statistics Finland, 1995). The proportion of very old people ( $>80$ years) in particular is growing (Statistics Finland, 1994).

O ld-age care was formerly institution-oriented, but presently over $90 \%$ of the elderly live in their own homes ( $N$ ational Board of Social Welfare in Finland, 1987). If they cannot manage in their daily life, home aid services are provided bylocal governmenthealthcare offices. About $5 \%$ of the aged live in old people's homes ( $N$ ational Board of Social Welfare in Finland, 1987). Service apartments for the elderly are increasing, and it is estimated that $3 \%$ of the retired will be living in assisted living facilities at theend of the century ( $M$ inistry of Social Affairsand $\mathrm{H}$ ealth, 1990).

Before World War II, homes for theelderlywereoften built outsidepopulation centers on a beautiful spot near a lake. They usually had a large garden with vegetables, berries and apple trees, and residents could participate in the garden work. O ver the last decades the tendency has been to build old people's homes in cities, ignoring the healing dimensions of nature and gardening.

In her dissertation, Erja Rappe is studying if it is possible to improve the physical and mental condition of the elderly living in institution-like settings by means of gardening. Because Finland was an agricultural society in the youth of the present-day aged people, they havedeveloped cognitiveand emotional skills related to nature and plants. In her first study Rappe interviewed 12 old peoplein a sheltered housing area to find out the meaningsgardening had to the residents. Preliminary results show that gardening was very important to the residents, who desired to practice their former abilities to understand and control their present environment. Gardening also had an important role in social relations. Rappe's next study will be a survey to find out how the personnel in the homes of elderly experience plants in their nursing work.

ECOLOGY, NATIME PLANTS, AND MAINTENANCE IN PARKS. Landscaping traditions in Finland are based on foreign ideas of landscaping. At present there is a new demand to find asustainablecombination of nature and gardening, introduce ecologically oriented approaches in landscaping, develop lines of action to restore poor nearby environments in population centres, learn how to increasebiodiversity, and learn more about extensive maintenance and natural plantcommunities(Pehkonen and J ansson, 1996). O ur wetland themeinterview study is collecting information and attitudes of interviewees concerning wetland plant communities, plant species, growing conditionsand human aspectsin using wetlandsin landscape construction. In amaintenance-intensitystudy, slidesare employed to discover residents' preferencesfordifferentmaintenancelevels(from low to high) for parksin theH elsinki area.

THE USE OF HORTICULTURE IN ENVRONMENTAL AND SCIENCE EDUCATION. Three master's theses focus on applying horticultural practices in environmental and science education at the lower level of the comprehensive school. O ne of the studies applies horticultural practices on a city farm used to educate school children, the second study on a school ground, and the third one in a biology classroom. The target is to produce teaching materials on how to use horticulture for environmental and science education.

\section{Conclusions}

The HIH approach gives a practical tool to bring gardening and peopleplant interaction closeto children, adults, and elderlyin their everyday life in cities. It is being practiced on an increasing scale in Finland. In the future we need more research results to convince authorities and sponsors that this is one effective way to improve nearby nature.

\section{Literature cited}

Evers, A-M . (ed.). 1996. Puisto, puutarhajaihmisen mieliala. Puutarhatieteen Julkaisuja 29. Yliopistopaino. H elsinki, Finland.

Evers, A-M . (ed.). 1998. Puisto, puutarhajaihmisen mieliala. 2. Seminaari. Puutarhatieteen Julkaisuja 33. Yliopistopaino. H elsinki, Finland.

H orelli, L. 1997. Challenges of children's participation in urban planning, p. 131-138. In: R. Camstra (ed.). Growing up in a changing urban landscape. Van Gorcum, Assen, The $\mathrm{N}$ etherlands.

H yvönen, M . 1922. Koulupuutarha. Sen tarkoitus, järjestely ja perustaminen. 2nd ed. O tava, H elsinki, Finland.

Kalervo, K. 1913. Koulupuutarha-aatteen kehitys meillä ja muualla. Weilin \& Göös, H elsinki, Finland.

Kalervo, K. 1915. O hjeita vaatimattomien koulu-ja oppilaspuutarhojen perustamiseen. Valistus, $\mathrm{H}$ elsinki, Finland.

Kauppinen, J. 1987. Siirtolapuutarhat kunnallisina palveluina. Kaupunkiliiton Julkaisu 379. Suomen Siirtolapuutarhaliitto ry. Suomen Kaupunkiliitto.

Kokkola, A. and H. Kotilainen. (eds.). 1997. Pieni on kaunista-projekti vuosina 1994-1996. Assn. Finnish Local and Reg. Auth.. N atl. Res. and Dev. $\mathrm{C}$ tr. Welfare $\mathrm{H}$ ealth, $\mathrm{H}$ elsinki, Finland.

L evander, L. 1998. From green fingers to green eyes. Exploring the conception of knowledge and knowledge construction of horticultural entrepreneurs. PhD diss. U niv. H elsinki. Ext. Euc. Publ. 19.

M inistry of Social Affairs and $\mathrm{H}$ ealth. 1990. Social welfare in Finland. Govt. Printing $\mathrm{Ctr}$. H elsinki, Finland.

$\mathrm{N}$ ational Board of Social Welfare in Finland. 1987. Old age welfare in Finland. Govt. Printing $\mathrm{Ctr}$. $\mathrm{H}$ elsinki, Finland.

Pehkonen, P. and J. Jansson. 1996. Viheralan tutkimu-ja kehittämistyö. Suomen Ympäristö 61. Ympäristöministeriö. H elsinki, Finland.

Statistics Finland. 1994. Katsaus ikääntyvien elinoloihin. Living Conditions 1994:1.

Statistics Finland. 1995. Population projection by municipalities 1995-2030. Population 1995:9.

Statistics Finland. 1996. Statistical yearbook of Finland 1996. vol. 91. Gummerus Kirjapaino O y. Jyväskylä.

Tiainen, H ., P. Keskitalo, H . Fiskaali, L. N iittymaa, and U. Raukko. 1984. Palstaviljely ja sen kansantaloudellinen merkitys. M aatilahallituksen julkaisuja 11, H elsinki, Finland. 